\title{
THE "UMBRELLA SOCIETY": A NEW CONCEPT FOR OBSERVING SOCIAL-ECONOMIC STRUCTURAL TRANSITION IN CHINA
}

\author{
ZHANG JIJIAO \\ INSTITUTE OF ETHNOLOGY AND ANTHROPOLOGY, \\ CHINESE ACADEMY OF SOCIAL SCIENCES
}

\begin{abstract}
Since the economic reforms and opening up of China in 1978, China has witnessed national development that has ushered in huge social and economic changes. This paper tries to answer the following questions concerning China's economic take-off: What is the relation between China's booming economy and its social-economic structural transition? What roles do governments and enterprises play? Although China claims to comprehensively deepen its market-oriented reform, and the government solely serves as a "referee", we found, through case studies of "local development" and "enterprise growth", that a major driving force of China's economic development is still the "umbrella relation" between local governments and enterprises. To be specific, local governments are patrons offering protection and preferential policy to local enterprises which are clients. Local resource allocation and economic-social development in many regions of China present a strong characteristic of an "umbrella society".
\end{abstract}

Keywords: umbrella society, social economic structural transition, China

\section{Introduction}

China has witnessed enormous economic development accompanied with social economic changes in the last 30 years, and it surpassed Japan in 2010 as the second largest economy in the world. Exploring the driving force of China's economic take-off, we bring forward several questions: 
What are the relations between China's booming economy and its economic-social structural transition? What roles did governments and enterprises play in the development?

\section{Theoretical Background and Analytical Framework}

\section{Theoretical preparation and research paradigm}

The totalitarian paradigm ${ }^{1}$ and modernization paradigm ${ }^{2}$ were dominant in the study of Eastern European socialism in the former Soviet Union and its associated Bloc before changes were implemented in China. However, the lack of explanatory power of these paradigms was exposed during the economic transition of China, the former Soviet Union, and Eastern Europe in the 1980s. In 1989, Victor Nee advanced his market transition theory, which led to the invention of a new research paradigm - neo-institutionalism. ${ }^{3}$ Neo-institutionalist sociologists made several influential studies of China's market transition. For example, Jean

\footnotetext{
${ }^{1}$ Andrew G. Walder (1986) claimed that a totalitarian society has two unique characteristics. The first one concerns with the ties between the Communist party and its supporters. In the view of totalitarianism, the relationship between a political party and its supporters is based on ideology, which remains a basic means of social mobilization after the success of the revolution. The other one can be called the atomization of society, which does not emphasize the differences between the private sector and the public domain, but believes that all social bonds that impede governing have disappeared directly. It is atomization of the general public that is not only a must for power, but also ensures the ability to carry out a total mobilization of the masses without any obstacle.

${ }^{2}$ The modernization paradigm claimed that as long as state power has been consolidated after a socialist revolution, the socialists are bound to focus on economic development, which requires modernization and introduction of modern technology. Correspondingly, industrialization and modern science and technology demand a set of appropriate modern values and institutions, which in turn will lead to institutional changes of the socialist system. Inevitably, the modernization process will, by its own logic, force socialist countries to rebuild themselves in accordance with the model of Western countries.

${ }^{3}$ The neo-institutionalism paradigm counters the trends of the modernization and totalitarian paradigms, which neglected the functions of institutions. It also differentiates itself from the institutionalism advocated by T.B. Veblen and J.R. Commons in the early twentieth century, referred to as the "new institutionalism" paradigm.
} 
Oi (1992, 1995, 1998, and 1999) proposed the local state corporatism theory, ${ }^{4}$ Andrew G. Walder (1995) proposed the local governments in an industrial firm theory, ${ }^{5}$ Nan Lin (1995) proposed the local market socialism theory, ${ }^{6}$., etc. Chinese scholars studied the functions of the local governments in promoting market transition (Hong and Cao, 1996), their roles in the transition period (Yang, 1998), the transition of the original type of economic-cultural patterns to a market-oriented type (Zhang, 2010), etc.

In studies of the social structures in the eastern world, Fei Xiaotong (1948) studied traditional rural society in China and proposed a new concept, namely the differential mode of association, ${ }^{7}$ which became a classic in the study of China's social structure. Six decades later, Zhang (2004) adapted the rural version of this theory to an urban version in his study of urban migrants. Similar to Fei, the Japanese anthropologist Nakane Chie (1967 in Japanese, 1972 in English) put forward the concept of a vertical-type society to describe the social structure of Japan. ${ }^{8}$ The concept not only became hotly debated, but it was also a model for researchers to re-analyze their native societies, inspiring huge research passions both inside and outside of Japan.

How should we consider the relations between market transition and social structural transition in China since economic reforms and the

\footnotetext{
${ }^{4}$ Jean Oi believes that "in the process local governments have taken on many characteristics of a business corporation, with officials acting as the equivalent of a board of directors. The merger of state and economy characterizes a new institutional development that I label local state corporatism...By local state corporatism, I refer to the workings of a local government that coordinates economic enterprises in its territory as if it were a diversified business corporation." (Oi 1992, 100-101)

${ }^{5}$ Walder's research into the role of the local government in economic development stems from J. Kornai. The relation between governments and enterprises is similar to the internal structural relation in a factory or an enterprise in which the role of governments as owners is similar to the role of chairmen of enterprises, and the role of enterprise managers is similar to the role of workshop directors in the enterprises. 6 "Local" refers to the local social and cultural infrastructure, "market" to the changes in the economic system, and "socialism" to the political ideology.

7 The main point of "The Differential Mode of Association" is that each individual in China is located in the center of his/her network circle, and he/she defines others by his/her personal connections.

${ }^{8}$ Nakane Chie believed that the characteristic of Japanese society is the vertical interpersonal social relation.
} 
opening up in the 1980s? Li Peilin (1992, 1994, and 1995) proposed the social structural transition theory, or the "another invisible hand" theory. $\mathrm{He}$ believed that China had been witnessing comprehensive social structural transition from an agricultural, rural, and semi-closed society to an industrial, urban, and open society. He claimed that the social structure provided considerable space and flexibility for change, in which a huge potential power could be generated from people's customs, behaviors, ethics, values, interests, and operating mechanisms. In China's rapid economic development and social transition, there exist three impacting powers on resource allocation and economic development: apart from the visible hand of state intervention and the invisible hand of market mechanism, there is "another invisible hand"-social restructure-which not only promotes social development, but also affects the ways of resource allocation and directions of industrial adjustment and economic institutional reform at a deeper level. The significance of this theoretical proposition lies in the fact that it has jumped out of the popular individualistic methodology of social science in the West and it establishes a new framework to explain China's economic structural reform and economic growth process. This theory has greatly influenced the social sciences in China (Zang, 2011).

\section{Hypothesis and Analytical Framework}

On 16 February, 2014, The Third Plenary Session of the 18th Central Committee of the Communist Party of China highlighted the role of markets in resource allocation as "decisive", which clearly indicated the expectation that the market, or market entities, would be the central focus of the economic development in the future, and which allocated the government the role of an impartial regulator, that is "referee". This move clarified the boundary between the government and the market, and indicated the direction of China's deepening all-round reform. However, one of the basic characteristics of contemporary China's market economy is that it retains public ownership as the mainstay, while developing diversified forms of ownership side-by-side. This localized economic system is known as the "official standard"; 9 not only do the governments at all levels have leading roles in resources allocation, but their

9 "Official standard" first appeared in the 1980s and was widely used due to its counterpart Gold Standard. It is an ideology that takes officials' will or interest as the top guide, and a social evaluation standard judged by official ranks. 
administrative powers also intensify in the existing vertical-appointment management system. In this case, what are the relations between the governments and the enterprises in the context that state-owned enterprises are the main body of the economy? Are relationships close or detached? If close, to what extent and what is the nature of the arrangement?

Applying the approaches of Karl Polanyi's $(1957)^{10}$ three types of economy, theories of Nee's market transition, Fei's differential mode of association, and Li's social structural transition, we argue that the social economic transition in China presents two distinct directions. One is the "umbrella society". Owing to China's rapid social economic development in which political reforms have lagged behind, and official management systems remain unchanged, one of the most typical results is the vertical-appointment system of the planned economy. In this case, there is ripe institutional environment for the strengthening of the official standard. In this context, the local governments act as the patrons and the enterprises act as the clients, forming the "umbrella relations" which play an important role in the local resource allocation and social economic development. This contrasts with the "cellular society". ${ }^{11}$ In this article, we shall mainly focus on the "umbrella society".

\section{Case Studies: Local Development and Enterprises Growth}

This section demonstrates features of the "umbrella society" in China's social economic transition, with data developed for two case studies through field surveys. These include, firstly, a local development in an island in Hainan Province in southern China, and secondly, the enterprise growth of two Chinese traditional herbal medicine companies.

\footnotetext{
${ }^{10}$ Polanyi (1957) pointed out that human economic mode of production can be generalized by three types, namely, market economy, redistribution, and reciprocity. 11 "Cellular society" refers to the transfer of powers and privileges from redistributors to direct producers during the transition period from a planned economy to a market economy, where the ordinary people gain more opportunities and their working enthusiasm and dominating power of residual products increase, and thus they work like bees. These people weave their cellular society through their network of relationships: private enterprises, individual enterprises, and freelancers increase as a result.
} 


\section{Case Study \#1: Local development - market transition of Xinglong and the rise of tourism under "umbrella relations"}

Since the market transition in the 1980s, Xinglong Overseas Chinese Farm (Xinglong) ${ }^{12}$ in Hainan Province, an island off the mainland in the South China Sea, has shifted from a planned economic system and management model to a socialist market economy, entailing a shift from a single economic structure to a diversified one. ${ }^{13}$

Xinglong is an agricultural SOE, established during a special period to assist the local government in managing the employment of overseas Chinese refugees. Xinglong has dual attributes: firstly, that of an economic organization as an SOE; and secondly, that of a political unit due to refugee resettlement. Consequently, reform and development of Xinglong had to take both economic development and political stability into consideration. In 1985, the central government of China decided to initiate the economic reform of Xinglong. ${ }^{14}$ According to the policy of "invigorating the domestic economy, and opening to the outside world", the major change in Xinglong occurred in the tourism economy, which had little relation to its traditional cropping and aquaculture industry, and it could avoid affecting its existing industrial structure and pattern of interests.

After nearly 30 years of development, Xinglong has shifted from an agricultural enterprise of a planned economy to an integrated enterprise involving agriculture, industry, commerce, and tourism. Tourism, a new-rise industry typical of a market economy, and its related industries, were Xinglong's most important economic contributors that accounted for 50 per cent of its 2003 revenue.

In Wanning City, Xinglong County of Hainan Province, where the Xinglong Overseas Chinese Farm is located, two different types of

\footnotetext{
12 Just like the 86 overseas Chinese farms in mainland China, Xinglong in Hainan Province is affiliated to the Overseas Chinese Affairs Office of the State Council. After 1985, it became an SOE at provincial level.

${ }^{13}$ Hainan is the hometown of the author, who had visited Xinglong in the 1980s. In order to complete this research, the author conducted field surveys twice, one in May 2011 with Elaine Ho and Guo Chunlin, and the other in August 2012 with Elaine Ho, Guo Chunlin, and Guo Xiaofei.

14 "State Council of CPCCC, Decision on Reform of the Economic Structure of Overseas Chinese farms" (1985), Chinese Communist Party Central Committee Document No. 26.
} 
economies can be easily noticed. The west side of the Sun River is dominated by the traditional economy and includes the headquarters of Xinglong, symbolizing the county's political and economic center, along with bazaars, the living area, old streets and shops, residential areas, and other facilities. The east side of the river is occupied by the emerging tourism economy, centered around the Overseas Chinese Tourist Centre, consisting of nine major tourist destinations nearby, three18-hole golf courses, and covering an area of 6000 acres $(2,400 \mathrm{ha})$, and the Tropical Botanical Garden which integrates botanical research, production, processing, tourism, and resource protection into one enterprise. To a certain extent, tourism constitutes Xinglong's "second national economic system".

Objectively, the rise of tourism can be attributed to its unique geological conditions, convenient transport facilities (located in the center of a popular tourism route in eastern Hainan with a cross-cutting highway), rich soil resources, charming tropical scenery, rich geothermal spas, and aromatic coffee. As a hometown to many overseas Chinese, it has been visited by a number of state leaders. Meanwhile, its fame, the thriving domestic tourism demand, and the internal investment needs, all contribute to its growth.

Apart from these factors, however, Xinglong's own market-oriented reform efforts cannot be ignored. Tourism has been set as the key to its revitalization since the 1990s, with the aim of building a travel leisure town to include sight-seeing, a wellness spa, and shopping facilities. In 1993, Xinglong was awarded the Famous Holiday Resort recognition by the Hainan Provincial Government. Nowadays, there are more than 58 restaurants and hotels with different styles (including one five-star hotel, and 11 four-star hotels) in the Overseas Chinese Tourist Centre, which receives 300 million tourists per year, becoming a major tourist site of Hainan Province. Statistics indicate that the tourist groups that stay for more than three days in Hainan spend at least one day in Xinglong.

As an SOE without a clear boundary between an administrative organization and an enterprise, what are the driving forces of Xinglong to promote its tourism-based, market-oriented economic reform?

With the patronage of the Overseas Chinese Affairs Office of Hainan Province and the Wanning City government, Xinglong adopted governmental administration as its organizational model, and a business operation that included its land, real estate, other assets, and staff management mechanism. In this way, the economic growth rate was regarded as the indicator of its performance. In order to maximize its 
profits, the Xinglong authority tried to utilize its political power to seize all the available resources, "making full use of the policy" to seek more political space and working around the "policy edge" to legitimately serve its self-interests.

The Xinglong authority mainly focused on the development and operation of its land and hot springs resources to develop local tourism. We take the Overseas Chinese Tourist Town led by Xinglong's governmental administration as an example to illustrate the booming tourism development of Xinglong. ${ }^{15}$

Xinglong Inn, predecessor of Hot Springs Guesthouse, was originally built for supporting hot springs tourism, and it then became the Overseas Chinese Tourist Town. Closely linked to the history of the farm, it witnessed the development of Xinglong. The Inn, built in 1959 to receive domestic and foreign guests, has received many state leaders of China, including Liu Shaoqi, Zhu De, Zhou Enlai, Deng Xiaoping, Jiang Zemin, Li Peng, Zhu Rongji, Hu Jintao, etc., as well as a number of foreign heads of state, ambassadors, and so on. After economic reforms and opening up in the 1980s, Xinglong made full use of its natural tourist resources to promote development of other industries. The Guest House was upgraded to Hot Springs Guesthouse in the 1990s, earning a three-star hotel rating with more than 250 rooms and annual reception capacity of 180,000 people. One part of the renovation made room for ordinary tourists while the other accommodations were retained for VIP receptions. In addition, a large floating restaurant was established on a small lake, which was able to accommodate hundreds of non-guests dining at the same time.

Also in the early 1990s, Xinglong embarked on a joint venture with a subordinate company of the Ministry of Public Security, with its land as stake due to its lack of initial capital, to co-develop a Health Park project around the Guest House. Later, Xinglong raised RMB 5 million (USD 766,000 , INR 51 million) through land transfer, and despite the skepticism of many officials, unilaterally invested RMB 4 million (USD 613,000, INR 41 million) to build Betel Park Hotel and six villas, imitating the Health Park model. Later, a businessman acquired the Betel Park Hotel for RMB 10 million (USD 1.5 million, INR 102 million) and sold it for RMB 13 million (USD 1.9 million, INR 133 million) afterwards. In August 2012, when we visited there, the Betel Park Hotel had been closed for quite a long time. Du Tianjiang pointed out, "Since we are from capitalist

15 Source: In-depth interview with Mr. Du Tianjiang (on 18 August, 2012), 73 years old, former vice director of Xinglong and descendant of Indonesian Chinese refugee. 
countries, we understand the way of capital flow. The Betel Park Hotel is used both for the image of overseas Chinese and for profit."

Xinglong also lacked management talent during that period. However, by operating the Hot Springs Guesthouse and the Betel Park Hotel, it cultivated hotel management experience, developed financial personnel, learned hotel design and operations, and also accumulated a sum of capital.

Xinglong invested and built another big hotel, Hot Springs Hotel, with RMB 14 million (USD 2.1 million, INR 143 million), of which 71 per cent of the construction cost came from the sale of the Betel Park Hotel and the remaining 29 per cent from rental fees. The Hot Springs Hotel consists of three sections. Section A was completed in 1992 and was visited by President Jiang Zemin the next year. Later, with capital accumulation, Xinglong reinvested in the Hot Springs Hotel and built sections B and C (20 villas). The four-star Hot Springs Hotel is a subsidiary SOE of Xinglong, covering an area of over 18 acres (7.2 ha) and a building area of $18,887.92 \mathrm{~m}^{2}$, with more than 449 luxury rooms, including 380 sight-viewing rooms, 6 sets of luxury large suites, 13 sets of small suites, and 50 poolside rooms.

The Overseas Chinese Tourism Town plans to cover an area of $20 \mathrm{~km}^{2}$, of which 60 per cent has been utilized and developed. By a rough calculation, the land covered by the Hot Springs Hotel (110 acres, 44.5 ha) and the Hot Springs Inn (about 10 acres, 4.0 ha), as well as lands, roads, and public spaces, probably does not exceed $2 \mathrm{~km}^{2}$. The remaining $10 \mathrm{~km}^{2}$ area has been divided into different plots by Xinglong and has been rented, sold, or transferred to more than 50 hotels, real estate developers, and tourist attractions. For example, the five-star Kangle Yuan Hotel occupies $55,000 \mathrm{~m}^{2}$, a four-star hotel named Silver Lake Holiday Inn occupies $11,000 \mathrm{~m}^{2}$, and Tropical Garden occupies 4 million $\mathrm{m}^{2}$.

As can be seen, the relations between the local governments (Overseas Chinese Affairs Office of Hainan Province and Wanning City) and Xinglong, and those between Xinglong and its affiliated companies, are not simply superior and subordinate relations but are also patron-client "umbrella relations".

We can see that under the patronage of the Overseas Chinese Affairs Office and the Wanning municipal government, Xinglong can be described as a client operator, controlled through the interventions of its affiliated companies through four levers. The first lever is enterprises management. To allow the local governments (Overseas Chinese Affairs Office of Hainan Province and Wanning City) and the client operator 
(Xinglong) to more effectively control the subordinate enterprises, contractual management was applied rather than privatization. For example, in the 1990s, by the application of contract management, Xinglong decentralized its daily management rights to affiliated companies (Xinglong Hot Springs Inn) and applied a bonus encouragement system to stimulate managers to improve efficiency and increase revenues. The contractor could bring up recommendations on such aspects as the investments, operations, and personnel issues of the restaurant, but the final decisions still rested with the local government or Xinglong itself.

The second lever is resource allocation power. The local government holds various assets allocated by the central government with a planned price and many scarce resources (such as land), and has the selective power to reallocate the resources. In 1993, Xinglong was listed as a noteworthy place of interest. The $10 \mathrm{~km}^{2}$ land developed by its Tourism Town has now been divided into different plots, which have been rented, sold, or transferred to more than 60 hotels, real estate developers, and tourist attractions.

The third lever is the administrative service, which includes assistance to the enterprises to obtain business licenses, product certifications, awards, tax-abatement opportunities, and even direct granting of administrative appropriations. For example, Xinglong assisted the Overseas Chinese Tourism Town to obtain business licenses for luxury hotels, including the two five-star hotels, that is the Hainan Aire Kangle Hot Springs Hotel and the Old Banyan Resort \& Spa Hotel, and 11 four-star hotels such as Treasure Island Resort \& Spa, Silver Lake Spa Resort, etc.

The fourth lever is the investment and financial grants, which are the local government's most effective leverage tools to guide the economic development. An example is Xinglong's investment in the construction of Hot Springs Guesthouse, Betel Park Hotel, and Hot Springs Hotel District $\mathrm{A}, \mathrm{B}$, and $\mathrm{C}$ in the 1990s.

To sum up, the reasons for Xinglong's market transformation were as follows: 1) the sense of independence spurred by fiscal pressures and its financial residual claim right; and 2) the shifting of its aim to facilitate economic development, improve revenue, increase employment opportunities, and form a corporation with affiliated enterprises resulting from excessive decentralization of administrative power. In its economic dimension, Xinglong brought affiliated companies into the administrative bureaucracy, forming a similar relationship between the boards of directors and operators. This new cooperation between the governments and the enterprises was summarized by Oi (1992) as "local state 
corporatism," and this local development model was summarized by Lin (1995) as "local market socialism".

\section{Case Study 2: Enterprise Growth; "Umbrella Relations" between the Beijing Municipal Government and Old-Brand Enterprises}

Another case of "umbrella relations" involving local government and enterprises was the development of two old-brand enterprises, China Quanjude Group (Quanjude) and Tongrentang (TRT), which the author studied from 2011 to 2014 (Zhang 2011, 2013, 2014).

\section{Quanjude}

Established in Beijing in 1864, Quanjude is a restaurant with a rich culinary history, with its Peking Roast Duck continuing today as its most exclusive menu item. ${ }^{16}$ Quanjude survived in spite of great financial difficulty through several major historical periods, such as the decline and fall of the late Qing Dynasty, the establishment of the Republic of China, the Warlord Era (軍閥時代), the Anti-Japanese War, the New Democratic Revolution, and the founding of the Peoples Republic. At one point, Quanjude actually suffered through such a conflict-ridden past that its fourth owner's wife pawned her dowry in order to maintain operations. After the founding of the PRC, the newly established Beijing Municipal Government attached great importance to old-brand enterprises and decided that brands like Quanjude should remain financially solvent. After the Beijing government injected capital, Quanjude survived and prospered again and became part of the first batch of enterprises that participated in the state-private partnership program in 1952. It was affiliated to the Beijing Administrative Bureau of Service Industry as an enterprise with capacity for foreign affairs receptions. The public-private partnership saved Quanjude from the brink of bankruptcy.

From the early 1950s, Premier Zhou Enlai frequently chose Quanjude's "All-Duck Banquet" for state receptions. ${ }^{17}$ Not only did

\footnotetext{
${ }^{16}$ Quanjude was founded by Yang Quanren from Ji County, Hebei Province. He invented the hanging furnace roasted duck. The author carried out a field survey at its Hepingmen store on November 15, 2013 and at Quanjude Museum.

17 Quanjude stores are important places for national receptions. Taking advantage of this celebrity effect, Quanjude designed a "celebrity wall" with pictures of three
} 
Premier Zhou proclaim an indelible interpretation of its brand as "integral, converging, and good faith", but he also suggested building branches at Qianmen, Chongwenmen, and Xuanwumen locations in Beijing city. However, these three outlets were assigned to different administrative departments. The Qianmen branch belonged to the Beijing Tourism Bureau while the other two belonged to the Beijing Service Bureau.

With the strong support from the Beijing Municipal Government, the foundation of China Beijing Quanjude Group on May 20, 1993 ushered in a new episode for Quanjude. In the following June, Quanjude and six other companies initiated the Beijing Quanjude Roast Duck Co. Ltd. In January 1999, Quanjude was awarded the title of "China Renowned Trademark", a first and unique case in the service trade of China. In April 2004, the Capital Tourism Group, Quanjude Group, and New Hansha Group, all implemented a strategic joint restructuring. The Capital Tourism Group became the largest shareholder in the Beijing Quanjude Roast Duck Group Co. Ltd. In January 2005, the Beijing Quanjude Roast Duck Co. Ltd. changed its name to China Quanjude (Group) Co. Quanjude then acquired a 30.9 per cent stake in the Beijing Huatian Food Group, becoming its largest shareholder, and formed a new group, Judehuatian Holding Ltd. In April 2007, a batch of famous restaurants such as Fangshan Restaurant, Fengzeyuan Restaurant, and Sichuan Restaurant also joined Quanjude. By now, China Quanjude (Group) Co. Ltd. has developed into a flagship enterprise for the catering industry covering roasting, baking, rinsing, Sichuan flavoring, Shandong flavoring, Palace flavoring, and Beijing flavoring.

\section{Tongrentang (TRT)}

Tongrentang (TRT) was founded in the Qing Dynasty in 1669 during the reign of Emperor Kangxi. The founder's family name was Le. The Les came to Beijing from Ningbo, Zhejiang province, during the Yongle period of the Ming Dynasty. Mr. Le Xianyang, a fourth generation descendant, became a royal doctor in the imperial hospital and later founded the TRT drugstore. In 1702, the third son of Le Xianyang

national leaders of China as well as foreign politicians. Apart from that, there is also a "signature wall" with signatures from hundreds of foreign ambassadors, which attracts a lot of customers, who stop and look. The "Golden Hall" on the fourth floor has applied modern multimedia technology and stage lighting effects, presenting a luxury atmosphere. 
expanded the drugstore into TRT Pharmacy. In 1732, it was designated to provide medicines to the royal pharmacy of the imperial palace of the Qing Dynasty. The TRT Pharmacy monopolized royal medicine for a total of 188 years, spanning eight generations of Qing emperors.

Starting from the 1952 socialist reformation, Le Songsheng, head of TRT, convinced his family to enter into a joint public-private partnership. On July 28, 1954, an 11-member working group took over the management of TRT. Then an asset liquidation group was set up and it drafted the public-private partnership agreement. On August 27, a public-private partnership reorganization meeting was held, resulting in both the public and the private signing of an agreement, symbolizing that this old-brand private pharmacy, after 258 years of operation, was now integrated into the socialist economy. The TRT workers were satisfied with this development and in fact felt liberated after that. Prior to this agreement, the TRT apprentices had to change their names as a condition of employment, which lowered morale, and to which they had no recourse. The public-private partnership allowed these workers to restore their original names, and they worked more productively. It was TRT that took the lead in the public-private partnership in 1954. Consequently, Le Songsheng was the very first manager to submit an application to the government, accepting the direct administration of the Beijing Municipal Government. In early 1955, Peng Zhen, Secretary of the Beijing Committee of the Communist Party of China, inspected TRT and held discussions with Le Songsheng. Peng affirmed Le's performance in the public-private partnership movement. Soon, Le was received by Chairman Mao Zedong and Premier Zhou Enlai in Zhongnanhai. It was the same year that Le was selected as the representative of the Beijing Municipal People's Congress, and he served as vice-mayor of the Beijing Municipal City. In addition, Le successively served as the representative of the 1st, 2nd, and 3rd National People's Congresses, and was deputy director of the All-China Federation of Industry and Commerce. In February 1985, the Beijing Municipal Government celebrated the 315th Anniversary Celebration of TRT at the Great Hall of the People. The CPC Central Committee and the State Council viewed TRT's development as an important economic issue and attached great importance to this commemoration. State leaders Li Xiannian, Peng Zhen, Wulanfu, Wang Zhen, Bo Yibo, Zheng Tianxiang, and Fang Yideng, along with other dignitaries, wrote more than 30 inscriptions honouring TRT.

A highlight of TRT's transformation was the establishment of the Factory Management Committee in 1956 with the aim of achieving 
democratic management. The Committee was a decision-making body rather than an executive one. Its establishment further improved the management system of TRT. Thanks to its active participation in this movement, TRT not only won the strong support of the Beijing government, but was also appreciated by China's top leaders and the central government, thus establishing the patron-client ties with the governments. This turned TRT from a "self-financing" private enterprise into an SOE, with strong protection and support of the local and central government.

The government's strong support in the development of TRT was evident in other areas as well. For example, the "TRT" trademark was China's first application for an internationally registered trademark under the Madrid System, and it was also the first registered trademark in Taiwan. In 1989, the State Administration for Industry and Trademark Office authenticated "TRT" as a well-known trademark and gave it special protection. In 1991, the TRT Pharmaceutical Factory was promoted to a "Grade One National Enterprise". In 1992, the TRT Group was founded; in July 1992, the Beijing Municipal Government had decided to bring all the resources of traditional Chinese medicine to Beijing and appointed TRT to consolidate all these resources into a corporate group. On July 3 , the 21 core units, including the Beijing Medicine Company, the TRT Pharmaceutical Factory, and the TRT Drugstore, etc. were incorporated into "China Beijing Tongrentang Group".

On August 19, the group's inaugural celebration was held at the Great Hall of the People. President Jiang Zemin wrote the inscription "Carry forward the tradition of quality first, and provide health service for the people" for TRT. In 1997, TRT was listed as the only pharmaceutical firm at the Shanghai Stock Exchange among the central government's listing of 120 large SOEs as experimental units in the reform to establish a modern enterprise system. In June, Beijing Tongrentang Co. Ltd. comprised six blue-chip subsidiaries, which were listed at Shanghai Stock Exchange in July, marking an important step forward by TRT in its establishment of a modern enterprise system. At that time, Tongrentang Group, spinning off assets of RMB 200 million (USD 30.5 million, INR 2.06 billion), successfully listed and raised more than RMB 300 million (USD 45.8 million, INR 3.09 billion) in capital. In 2000, TRT established Heji (Hong Kong) Pharmaceutical Co. Ltd. in Hong Kong and was listed on Hong Kong's Growth Enterprise Market (HKGEM-創業板). It was the first mainland SOE to achieve a successful spin-off listing. TRT raised funds of HKD 238,784,000 (USD 30.7 million, INR 2.07 billion) from HKGEM, 
taking a key step towards TRT products entering the international mainstream market. This was the first case of a spin-off A-share that listed on H-shares, known as the "TRT mode". In July 2010, with the authorization of the Beijing Municipal Government, Beijing Tongrentang (Group) Co. Ltd. was officially launched, which marked the establishment of a corporate system and a major change in its institutional system. Currently, TRT has three main enterprises under its overall group framework, namely, the modern pharmaceutical industry, retail business and medical services, and its "1032" project group (10 subordinate companies, two large production bases, two hospitals, and two centers). TRT now has two listed companies domestically and internationally, more than 800 retail stores, and 28 overseas joint ventures (stores) across 15 countries and regions. From 2010-2011, the restructuring program of Tongrentang Group and its pluralism strategy were initiated.

In the development of Quanjude and TRT, the patron-client relationship can be clearly seen, including government protection of their brands, supports for their upgrades, expansion and issuance of shares over domestic and overseas stock markets, and encouragement for the standardization and diversified development of these enterprises. Supports of the central government and Beijing Municipal Government have become the most reliable resources for capital accumulation and expansion of both the enterprises. The patron-client relationships between the governments and the enterprises enhanced the development of their own strengths. As two successful old-brand enterprises, their development indicates that government's direct management can bring a powerful momentum for the enterprises and correspondingly enhance their own competitiveness.

\section{Discussion: "Umbrella Relations" in Social Structural Transition - Another Invisible Hand}

What can be found in the above two cases is that, apart from the two hands (the visible hand of the government and the invisible hand of the market) influencing resource allocation and economic-social development, the existence of "umbrella relations" between governments and enterprises is also a special way of resource allocation.

In the case of enterprise growth, Quanjude and TRT were turned from family-owned businesses into SOE subsidiaries of the Beijing Municipal Government through public-private partnerships, soon after the foundation 
of PRC. Due to the special relationships, they became the focus of both local and central government support in the government-led planned economy. Accordingly, they received a wide range of assistance in funding, factory construction, technology, staff, and preferential policies, and thus quickly became the leading enterprises in their respective industries, that is food and medicine. In the aftermath of China's economic reform and opening up in 1978, many related strategies were tried to disengage SOEs from governmental control. However, Quanjude and TRT still had the privilege of strong support from the Beijing Municipal Government under the policy of building bigger and stronger SOEs. This affected the special subsidiary relationship between the enterprises and the governments in three major ways: 1) government protection of brands and support for their upgrade and expansion; 2) government support in issuance of shares over domestic and overseas stock markets; and 3) guidance to lead the standardization and diversified development of these enterprises. Thus, SOEs have the competitive advantage to fully utilize the resources from both the government and the market.

In the case of local development, Xinglong and its subsidiary enterprises seek protection of their interests through various "umbrellas". On one hand, under the patronage of the Overseas Chinese Affairs Office of Hainan Province and Wanning Municipal Government, Xinglong plays dual roles: one as an agent for national interests, and the other as an actor pursuing its own interests. Market transition and fiscal reform endowed Xinglong with the incentive to pursue its self-interest and was accorded plenty of deference for action. The Xinglong authority was different from the previous grassroots authorities for it involved its own interests. Thus, Xinglong transitioned from an "agent of governments of higher levels" before 2007 to a "profit-seeking operator", particularly because its relationship of administrative subordination transferred from Hainan Provincial Government to Wanning City. On the other hand, after the market-oriented reforms, the local government of Xinglong formed various kinds of protective "umbrella relations" with its affiliated enterprises, including a "father-type umbrella relation" with subordinate enterprises (for example, Hot Springs Guesthouse, Hot Springs Hotel), a "relative-type umbrella relation" with joint enterprises (Kangle Yuan), and a "friend-type umbrella relation" with the private enterprises (for example, Silver Lake Resort \& Spa). In addition, the formal and informal "umbrella relations" between the local governments of Xinglong and the local enterprises were often converted to individual "umbrella relations" between the government officials and the local entrepreneurs. 


\section{Another invisible hand: "Umbrella Relations" from social structural transition}

Based on case studies, we found that in the social structural transition in China, as a special method of resource allocation, the fundamental or structural elements of the "umbrella society" consist of localized management, official standardization, and SOEs. Localized management and official standardization gave rise to the patron-client "umbrella relations" between the governments and the enterprises, based on Fei Xiaotong's differential mode of association in certain fields. In this context, the local governments and the local state-owned enterprises still kept the original and close patron-client "umbrella relations", even though great social transformation had taken place in many places of China. Regardless of the extent of the planned economy or the economic transition period, the priorities of government administration and resource allocation were always tightly related to the closeness of the "umbrella relations".

During the transition from the planned economy to a market economy, the original planned economy disintegrated while the new economic model had not yet been established, which caused an institutional rupture, forming an "institutional hole" (Bian and Zhang, 2001). Local government had to play an active role to cover the defects of the institution. Meanwhile, local governments held special resources (such as land, capital, etc.) so that they had the leverage to participate in the economic development. Studies have shown that the fiscal and tax policies of local governments have significant influence on the promotion of technological innovation ( $\mathrm{Li}$ and Lin, 2013). It is in this way that we can see why local governments in China have been playing a much more active role than their counterparts in a mature market economy from the perspective of economic transition. As the saying goes, "great trees are good for nothing but shade": the formal relationships between local governments and enterprises, and the informal relationships between local officials and private entrepreneurs formed formal and informal "umbrella relations" respectively, which is reflected by the strong political and economic protection of the governments granted to the related enterprises. For example, at the beginning of the market transition, a regulation called "dual-track pricing system" was implemented. Local governments held the distribution rights to a large part of the resources by a "planned price" (low price). The closeness of "umbrella relations" between the governments and the enterprises led to the governments carrying out selective "care" of 
those enterprises which they supported. Such were the Beijing Municipal Government's preferential policies to support Quanjude and TRT, and the Hainan Provincial Government's preferential policies to support Xinglong.

\section{Conclusion}

China claimed that its "comprehensive deepening reform" was to allow the market or market entities to take decisive action (act as "players"), while the government's main function was to call the balls and the strikes as a regulator, that is, a "referee". However, we found that, based on the case studies of local development and enterprise growth, one of the major driving forces of China's economic take-off over the past 30 years has been the "umbrella relations" between the businesses and the governments in the context of social economic transitions. These patron-client "umbrella relations" between the enterprises and the governments are important ways of resource allocation, which might be much more important than the enterprises' market development capacity. Whether the firm is Xinglong Overseas Chinese Farm or old-brand businesses such as Quanjude and TRT, they are all state-owned enterprises, which are the main driving forces of China's economic rise.

Relations between governments and the enterprises play a vital role in many parts of China, despite the great transformation. We conclude that under territorial management and official standardization, the relationships between the enterprises and the governments are patron-client umbrella relationships. It is in this context that local resource allocation and social economic development still present a strong characteristic of an "umbrella society".

\section{References}

Bian, Yanjie and Zhang Wenhong (2001). 'Economic Reform, Social Network and Occupation Mobility.' Social Science in China 2, 77-89.

Chie, Nakane (1972). Japanese Society. University of California Press.

Fei, Xiaotong (1948). From the Soil: The foundations of Chinese Society, Shanghai: Guancha.

Hong, Yinxing and Cao Yong (1996). 'The Function of Local Governments in the Economic Transformation Period,' Economic Research Journal5, 22-8.

Karl, Polanyi (1957). The Great Transformation. Boston: Beacon Press. 
Li, Cuizhi, Lin Zhouyu (2013). 'The Influence of Government Taxation Cuts on the Technological Innovation of Enterprises.' Journal of Yunnan University of Finance and Economics6, 146-54.

Li, Peilin (1995). 'Another Invisible Hand: Transformation of Social Structure.' Chinese Social Science 5, 3-17.

—. (1994). 'Another Invisible Hand: Rediscussion.' Sociological Studies 1, 1-8.

- (1995). 'The Influence of Social Structural Transformation on the Resource Allocation.' Chinese Social Science 1, 70-82.

Lin, Nan (1995). 'Local Market Socialism: Local Corporatism in Action in Rural China.' Theory and Society24 (3), 301-54.

Nee, Victor (1989). 'A theory of Market Transition: From redistribution to Market.' American Sociological Review54 (5), 663-81.

Oi, Jean, (1992). 'Fiscal Reform and the Economic Foundation of Local State Corporatism in China.' World Politics 45(1), 99-126.

- (1995). 'The Role of the Local State in China's Transitional Economy.' China Quarterly 144, Special Issue: China's Transitional Economy, 1132-1149.

- (1998). 'The Evolution of Local State Corporatism.' In Andrew Walder (eds.), Zouping in Transition, The Process of Reform in Rural North China, Cambridge, Massachusetts: Harvard University Press.

—. (1999). 'Local State Corporatism.' In Jean Oi(ed.), Rural China Takes Off: Institutional Foundations of Economic Reform, Berkeley: University of California Press.

Walder, Andrew G. (1986). Communist Neo-Traditionalism: Work and Authority in Chinese Industry. Berkeley: University of California Press.

- (1995). 'Local Governments as Industrial Firms.' American Journal of Sociology 101 (2), 268-69.

Yang, Ruilong (1998). 'Three-stage Theory of China's Institutional Changes.' Economic Research1, 3-10.

Zang, Deshun (2011). 'Social Structural Transformation of China.' Thought Frontier 4, 54-8.

Zhang, Jijiao (2004). 'The Differential Mode of Association: from Rural Version to Urban Version.' Ethnic Studies6, 50-9.

—. (2010). 'Economic-cultural Patterns from "Rural" to "Urban": A Study on New Migrants of Ethnic Minorities in China.' Thoughts Frontier1, 14-21.

-. (2013). 'The Relationship between Enterprise and Government: Case Study on Two "Chinese Old Brand" Companies (Heniantang, 
Tongrentang),' Journal of Chinese Literature and Culture, Kuala Lumpur: University of Malaya, Vol. 1, No.2, 1-24.

- (2014). 'Long History of Business Tradition in an Emerging Economy, China-A Study on China's Old Brand Enterprises,' Journal of Chinese Literature and Culture, Kuala Lumpur: University of Malaya, Vol. 2 No.2, 107-19.

Zhang, Jijiao et al.(2011) The Old Brands Blue Book: The Development Report of China's Old Brands Enterprises (2011).Beijing: Social Sciences Academic Press

Zhang, Jijiao and Liu Weihua (2014). The Old Brands Green Book: The Case Study and Development Report of China's Old Brands Enterprise (2013-2014). Beijing: Chinese Literature Press. 